\title{
Treating lower limb muscle cramps: a Cochrane systematic review
}

\author{
Fiona Hawke $e^{1,2^{*}}$, Kate Walter ${ }^{2}$, Vivienne Chuter ${ }^{2}$, Joshua Burns ${ }^{1,3}$ \\ From Australasian Podiatry Council Conference 2011 \\ Melbourne, Australia. 26-29 April 2011
}

\section{Background}

Muscle cramps affect approximately 1 in 3 people in the general community each year. Many interventions are available for lower limb cramps, but not all are efficacious or supported by evidence. Many treatments are controversial, no treatment guidelines exist, and many people experience no benefit from the interventions prescribed. In clinical trials, no drug treatment for cramps has demonstrated consistent effectiveness and safety and none are approved by the Australian Pharmaceutical Benefits Scheme or the American Food and Drug administration for the most common form of cramp; nocturnal leg cramps. Due to the unclear risk/benefit ratio of many drug treatments, patients are encouraged to try non-drug treatments. The aim of this project was to systematically review the evidence for non-drug treatments for lower limb cramp.

\section{Methods}

We searched MEDLINE, EMBASE and CENTRAL up to April 2010 for randomised controlled trials of any type of non-drug treatment for lower limb cramp in adults and children. Review methods were according to a peerreviewed Cochrane protocol.

\section{Results}

1,284 potentially relevant trials were retrieved and screened for inclusion. Trials were translated from Swedish, French and German. Authors of five trials were requested to provide more information. Of these studies, four have been excluded and the inclusion of the final study is pending the provision of additional

\footnotetext{
* Correspondence: Fiona.Hawke@newcastle.edu.au

'Discipline of Paediatrics and Child Health, The University of Sydney, Westmead, NSW, 2145, Australia

Full list of author information is available at the end of the article
}

information by the author. Complete results will be presented at the conference.

\section{Conclusions}

This systematic review identifies a desperate need for clinical research of non-drug therapies for lower limb muscle cramps. We are now investigating factors associated with lower limb muscle cramp to help identify non-drug therapeutic targets for sufferers of this common complaint.

\section{Author details}

'Discipline of Paediatrics and Child Health, The University of Sydney, Westmead, NSW, 2145, Australia. ${ }^{2}$ Podiatry Program, The University of Newcastle, Ourimbah, 2258, Australia. ${ }^{3}$ Institute for Neuroscience and Muscle Research, The Children's Hospital at Westmead, Sydney, NSW, 2145, Australia.

Published: 20 May 2011

doi:10.1186/1757-1146-4-S1-017

Cite this article as: Hawke et al.: Treating lower limb muscle cramps: a Cochrane systematic review. Journal of Foot and Ankle Research 2011 4(Suppl 1):017.
Submit your next manuscript to BioMed Central and take full advantage of:

- Convenient online submission

- Thorough peer review

- No space constraints or color figure charges

- Immediate publication on acceptance

- Inclusion in PubMed, CAS, Scopus and Google Scholar

- Research which is freely available for redistribution
C Biomed Central

\section{Biomed Central}

(c) 2011 Hawke et al; licensee BioMed Central Ltd. This is an open access article distributed under the terms of the Creative Commons Attribution License (http://creativecommons.org/licenses/by/2.0), which permits unrestricted use, distribution, and reproduction in any medium, provided the original work is properly cited. 